i Europie. Przedmiotem wystąpienia Dominiki Palecznej (IINiSB UW), zatytułowanego Metody badania użyteczności systemów informacyjnych, były systemy informacyjne typu discovery. Celem badań autorki była identyfikacja i analiza elementów interfejsu użytkownika w tej klasie systemów oraz wybrane formy interakcji z użytkownikiem, które oceniano z punktu widzenia ich użyteczności.

Konferencję zakończyła dyskusja panelowa, prowadzona przez przewodniczącą Komitetu Programowego - prof. B. Sosińską-Kalatę, a do uczestnictwa w niej zaproszeni zostali obecni drugiego dnia konferencji moderatorzy wszystkich sesji: dr hab. Katarzyna Materska, prof. UKSW (Biblioteka UKSW), prof. Jadwiga Woźniak-Kasperek, dr hab. Małgorzata Kisilowska (obie z IINiSB UW) i dr hab. Mirosław Górny, prof. UAM (IJ UAM). Moderatorzy sesji dyskutowali na temat poruszonych podczas konferencji zagadnień i podsumowali moderowane przez siebie sesje, zachęcając obecnych do podjęcia dyskusji. Wśród końcowych wniosków sformułowane zostały m.in. następujące tezy: humanistyka cyfrowa nie jest nową dyscypliną nauk humanistycznych, ale nową przestrzenią badawczą i informacyjną (J. Woźniak-Kasperek); faktyczny przełom w uprawianiu humanistyki wiąże się z wykorzystaniem w niej technik eksploracji wielkich zasobów danych (big data) (M. Grabowska); obecnie w praktykach badawczych humanistów widoczne jest najczęściej przenoszenie zachowań i postaw tradycyjnych do przestrzeni cyfrowej; rozwój humanistyki cyfrowej otwiera nowe pola badań dla nauki o informacji, a równocześnie wymaga rewizji programów kształcenia praktyków, po to, aby profesjonalistom informacji zapewnić kompetencje odpowiednie do sprawnej obsługi potrzeb informacyjnych nie tylko badaczy e-humanistyki, ale całego środowiska naukowego, którego warsztat badawczy i komunikacja w coraz większym stopniu migrują do przestrzeni cyfrowej (B. Sosińska-Kalata).

Na zakończenie przewodnicząca Rady Naukowej Konferencji, prof. B. Sosińska-Kalata podziękowała wszystkim uczestnikom i komitetowi organizacyjnemu. Podczas dwóch dni obrad w dziewięciu sesjach wygłoszono łącznie 37 referatów. Konferencja zgromadziła uczestników z pięciu państw (Francja, Meksyk, Wielka Brytania, Litwa i Polska), z dwóch kontynentów (Europa i Ameryka Północna). Organizatorzy zapowiedzieli publikację wygłoszonych referatów.

Monika Halasz-Cysarz Marcin Roszkowski Instytut Informacji Naukowej i Studiów Bibliologicznych Uniwersytet Warszawski

Nadestano: 10.07.2015.

\title{
II Ogólnopolska Konferencja Naukowa „Homo Communicativus. Przestrzeń informacyjna współczesnej nauki" (Toruń, 25-26 czerwca 2015 r.)
}

W czerwcu 2015 r. już po raz drugi w Instytucie Informacji Naukowej i Bibliologii Uniwersytetu Mikołaja Kopernika w Toruniu zorganizowano konferencję „Homo Communicativus”. W zamierzeniu

\footnotetext{
4 Pierwsza Ogólnopolska Interdyscyplinarna Konferencja Naukowa Homo communicativus z podtytułem Współczesne oblicza komunikacji i informacji, odbyła się w Toruniu w dniach 24-25. czerwca 2013 r.
} 
spotkanie miało służyć zaprezentowaniu najnowszych badań dotyczących nowych kanałów informacji i komunikacji w nauce i ich wykorzystania, indywidualnej przestrzeni informacyjnej naukowców, zagadnień związanych z oceną publikacji naukowych oraz naukowych zasobów informacyjnych. Przedmiotem miała być też dyskusja związana z usługami informacyjnymi i ich wykorzystaniem w różnych dziedzinach naukowych ${ }^{5}$.

Podczas dwóch dni obrad wygłoszono wszystkie z 30 zaplanowanych w programie referatów, odbyły się dwie dyskusje panelowe, a spotkaniu towarzyszyła wystawa „Mapowanie nauki” (“Places \& Spaces”).

Konferencję rozpoczęła przewodnicząca Rady Naukowej Konferencji i dyrektor IINiB UMK dr hab. Ewa Głowacka, prof. UMK wraz z dziekanem Wydziału Nauk Historycznych UMK - prof. Jackiem Gzellą oraz kuratorem wystawy „Places \& Spaces” w Polsce, dr Veslavą Osińską. Ewa Głowacka powitała wszystkich uczestników, przedstawiła zarys programu konferencji, akcentując najważniejsze według organizatorów wątki oraz podziękowała instytucjom patronującym (MNiSW, EBIB, TVP Bydgoszcz), sponsorującym (Elsevier, Tabulus, Academica, Fundacja Amicus Universitatis Nicolai Copernici oraz Thomson Reuters). Jacek Gzella zauważył, że obecna konferencja w porównaniu do odbywającej się przed dwoma laty kładzie większy nacisk na humanistykę, co powinno przedstawicieli nauk humanistycznych, do których zalicza się dyscyplina informatologia i bibliologia, napawać optymizmem. Na koniec zabrała głos Veslava Osińska, przedstawiając informacje o wystawie map wiedzy, których odsłona ma już dziesiątą generację.

Referaty pogrupowano w sześć sesji, cztery z nich (20 wystąpień) odbyły się pierwszego dnia, pozostałe 10 w dwóch sesjach - drugiego dnia konferencji.

W otwierającej konferencję sesji pierwszej, moderowanej przez dr hab. Ewę Głowacką, prof. UMK, a zatytułowanej „Tradycyjne i nowe przestrzenie badawcze bibliologii i informatologii” wystąpiło sześciu prelegentów: Wiesław Babik (IINiB UJ) przedstawił referat Ekosystem informacyjny człowieka w 21 wieku. Autor rozwijał wątki ekologii informacji, podjął próbę zdefiniowania pojęcia ekosystemu informacyjnego oraz starał się odpowiedzieć na pytanie, jak funkcjonować w obecnym nadmiarze informacji, sugerując, że antidotum jest słuchanie głosu rozsądku i związany z tym umiar, na którym bazuje idea zrównoważonego rozwoju realizowana w wielu dziedzinach życia. Bożena Koredczuk (IINiB UWr) zaprezentowała referat Bibliologia a naukoznawstwo. Wzajemne powiazania i potrzeba wspótpracy dla spoteczeństwa informacji $i$ wiedzy, ukazując wspólne obszary badawcze naukoznawstwa oraz bibliologii i informatologii, a także wiedzę z zakresu naukoznawstwa jako nieodłączny element wyposażenia warsztatowego pracowników książki i bibliotek. Autorka wskazała na biografię lekturową jako nowy problem badawczy. Następnie Jacek Ladorucki (KBiIN UŁ) w referacie O czym nie można teoretyzować, trzeba opowiedzieć, czyli o poszukiwaniu doxa bibliologii w dorobku naukowym profesora Janusza Dunina zaprezentował osobę tego znanego w środowisku bibliotekarskim humanisty, bibliologa i bibliofila oraz interdyscyplinarność jego badań, skupionych wokół historii kultury masowej, socjologii książki i czytelnictwa, które kierowały go na nowe, niezbadane i czasem lekceważone przez innych obszary badawcze. Etyka informacyjna. Od bibliotekarstwa po bioinformatyke medyczna była tematem referatu Moniki Halasz-Cysarz (IINiSB UW). Prelegentka przedstawiła niejasności związane z początkami tej subdyscypliny (bibliotekoznawstwa czy filozofii?), podsumowała badania zagraniczne, następnie omówiła nazewnictwo polsko- i angielskojęzyczne (information ethics - etyka informacyjna, infoethics - infoetyka, ethics of information - etyka informacji), by na końcu, ukazując obszary badawcze etyki informacyjnej, wskazać na powiązania z badaniami specjalistów z zakresu informatologii i bibliologii oraz innych dziedzin nauki i sztuki, a także zachęcić do zainteresowania się tym słabo jeszcze znanym w Polsce zagadnieniem badawczym. Przedostatni referat w sesji pierwszej przedstawił Marcin Karwowski (IINiB UMK). W prezentacji pt. Bibliologia $i$ informatologia - obszary badań $i$ ich finansowanie w ramach wybranych konkursów NCN przedstawił wyniki analizy grantów badawczych.

\footnotetext{
${ }^{5}$ http://www.inibi.umk.pl/homocommunicativus2/

${ }^{6} \mathrm{http} / / / \mathrm{scimaps}$. org/
} 
Zebrane dane wskazują na to, że maleje zarówno liczba projektów otrzymujących dofinansowanie, jak i kwota, przy czym średnia wartość projektu rośnie. Ok 20\% podmiotów realizuje ok. 80\% projektów. Wiodącymi ośrodkami są UW, UJ i UWr. W dyscyplinie bibliologia i informatologia jest obecnie 19 dofinansowanych projektów, średnia wartość każdego z nich to ok. 165 tys. zł, a największym w kolejności wysokości dofinansowania jest projekt realizowany na Uniwersytecie Pedagogicznym w Krakowie przez dr hab. Grażynę Wronę (ponad 700 tys. zł; co pod kątem kwoty dofinansowania plasuje go na 11. miejscu rankingu kwot obecnych dofinansowań). Wiodącym tematem grantów w naszej dyscyplinie są: zasoby cyfrowe, dostęp cyfrowy oraz nowe technologie informacyjno-komunikacyjne. Sesję zakończył Marek Nahotko (IINiB UJ) referatem Cybertekst i jego cybergatunki w cybernauce. Autor zauważył, że pojęcie cybertekstu naukowego jako bardzo nieostre - obejmuje wypowiedzi od pojedynczych zdań, pojęć i terminów po uniwersalne, globalne dokumenty. Przy omawianiu cybergatunku wskazał na trójkę RDF - pojedyncze stwierdzenia o strukturze przedmiot-predykat-obiekt, uzupełnione kontekstem. Cybernauką nazwał naukę uprawianą w cyberprzestrzeni.

W ramach drugiej sesji, zatytułowanej „Bibliometryczny aspekt badań bibliologicznych i informatologicznych" i moderowanej przez dr hab. Małgorzatę Kisilowską (IINiSB UW), referaty wygłosiły cztery osoby. Jako pierwsza zaprezentowała wyniki swoich badań Ewa Rozkosz (Dolnośląska Szkoła Wyższa), której referat Wytwarzanie nierówności w imię równości. Impact factor w awansach naukowych stanowił analizę możliwych skutków wprowadzania minimalnych wartości wskaźników Impact Factor i Sumarycznego Impact Factor do uczelnianych procedur oceny publikacji w awansach naukowych. W kolejnym referacie pt. Dwa obrazy nauki. Analiza zawartości prasy i bibliometryczna analiza cytowań $w$ badaniach nad źródtami wiedzy Anna Łach (IINiB UWr) przybliżyła problem wykorzystania różnych metod analizy zawartości gazet i magazynów do badań nad źródłami wiedzy, pozwalającymi ilustrować obraz nauki, porównywany później przy pomocy współczynnika korelacji Pearsona z obrazem wynikającym z analizy danych bibliometrycznych. Kolejnym zaprezentowanym referatem było wystąpienie Marcina Kozakowskiego (Thomson/Reuters), zatytułowane Bibliometryczne spojrzenie na dorobek naukowy. Wykorzystanie Web of Science i InCites do oceny badań naukowych i planowania strategicznego, które dotyczyło wykorzystania narzędzi analityki bibliometrycznej do oceny efektywności instytucji i badaczy. W oparciu o moduły i narzędzia udostępniane w ramach InCites, przygotowany został kolejny referat - Dominiki Czyżak (Biblioteka Uniwersytecka w Toruniu) - pt. Uniwersytet Mikołaja Kopernika w świetle danych InCites - konkretnie. W jego ramach zaprezentowane zostały wyniki analizy umożliwiającej zlokalizowanie wydawnictw, w których reprezentacja pracowników UMK jest najwyższa, co pozwala na określanie skali oddziaływania efektów badań naukowych różnych jednostek, poprzez generowanie odpowiednich rekordów dla poszczególnych okresów zarejestrowanych w Web Of Science.

Sesja trzecia, „Otwartość czy zamknięcie współczesnej nauki?”, moderowana przez dr hab. Małgorzatę Góralską (IINiB UWr), poświęcona została idei otwartości i dzielenia się wiedzą oraz zagadnieniom open access i open data. Dorota Fortuna (Biblioteka Narodowa - Academica) w prezentacji zatytułowanej Academica - cyfrowa wypożyczalnia jako źródto wiedzy prezentowała możliwości i funkcjonalności tej Cyfrowej Wypożyczalni Publikacji Naukowych, uruchomionej w 2014 r. przez Bibliotekę Narodową. Następnie Dominic Mitchell (DOAJ) w angielskojęzycznej prezentacji pt. You can't measure quality: the perception of low quality in open access and what DOAJ is doing about it omówił inicjatywę DOAJ, w której obecnie indeksuje się prawie 10.5 tys. czasopism. Polska pod względem liczby czasopism zamieszczonych w DOAJ znajduje się na 12. miejscu. Prelegent wskazywał na problemy, z którymi boryka się DOAJ (jak ocenić jakość czasopisma, jakie są przesłanki jakości, jak oceniać zawartość i samo źródło informacji). Zauważył, że bardzo ważna jest jawność i transparentny system oceny oraz wsparcie redaktorów. Zachęcał do pracy na rzecz DOAJ w ramach wolontariatu (obecnie trwa rekrutacja w różnych krajach). Marzena Świgoń (Instytut Historii i Stosunków Międzynarodowych UWM w Olsztynie) przedstawiła referat Udział naukowców w projektach $i$ stażach a dzielenie się wiedza. W świetle tych badań, doświadczenie w realizowaniu grantów naukowych (indywidualnych, zespołowych oraz międzynarodowych), a także uczestniczenie w stażach (krajowych i zagranicznych) miało pozytywny 
wpływ na takie analizowane zmienne, jak m.in.: częstotliwość rozmów zawodowych, zadowolenie ze stopnia wykorzystywania własnej wiedzy poza uczelnią, postrzeganie swoich rozmówców w kontekście dzielenia się wiedzą, a także wykorzystywanie narzędzi i technologii wspierających wymianę wiedzy i informacji. Adam Jachimczyk (Instytut Dziennikarstwa i Informacji Uniwersytetu Jana Kochanowskiego w Kielcach) zaprezentował referat Open Data. Casus polskich instytutów badawczych. Prelegent wskazał na dane ogólnie dostępne w Internecie, które użytkownik może pobierać, rozpowszechniać, modyfikować i przetwarzać w dowolnym celu bez żadnych ograniczeń natury prawnej lub technicznej, jako na nabierający znaczenia aspekt idei open access. Autor referatu znalazł 116 instytutów badawczych w Polsce, zatrudniających łącznie ok. 40 tys. pracowników i na potrzeby referatu przestudiował 328 baz danych prowadzonych przez te instytuty (tryb, typ danych, format, ograniczenia w dostępie, warunki wykorzystania danych). Zauważył, że są korzyści płynące z otwierania danych, ale również pojawiają się problemy i obawy. Zdaniem referenta jednak, zamykanie dostępu do tego typu danych badawczych skutkuje ograniczeniem innowacyjności w nauce i blokuje współpracę naukową. Sesję trzecią zakończył referat Magdaleny Ostrowskiej (IINiB UMK), Dedykowane serwisy służace udostępnianiu książek naukowych, w którym kontynuowane były wątki otwartego dostępu do utworów i danych naukowych.

Czwarta, ostatnia tego dnia sesja została zatytułowana „Naukowiec w przestrzeni wirtualnej” i była moderowana przez dr hab. Zdzisława Gębołysia, prof. UKW (KINiB Uniwersytetu Kazimierza Wielkiego w Bydgoszczy). Jako pierwsza wystąpiła Grażyna Piechota (IINiB UMCS) z referatem Przejawy bibliofilstwa w sieci - książek poszukiwanie, kolekcjonowanie, badanie, wskazując na rolę Internetu we współczesnej promocji różnych działań bibliofilskich i przedstawiając egzemplifikacje tego typu aktywności (np. ławki tworzone z książek, promocje zbiorów i kolekcji w serwisach społecznościowych). Agnieszka Kida-Bosek (również IINiB UMCS) omówiła Prezentacje czasopism literacko-artystycznych w przestrzeni wirtualnej, zastanawiając się nad tym, jak nowe technologie zmieniły segment owej prasy. Bernardeta Iwańska-Cieślik (podobnie jak moderator sesji, z KINiB UKW w Bydgoszczy) w referacie Informacja o nowych publikacjach pracowników polskiej bibliologii i informatologii w przestrzeni sieciowej zaprezentowała wnioski z badania polegającego na przeanalizowaniu obecności 259 informatologów i bibliologów w przestrzeni sieciowej i stopnia wykorzystania przez nich różnego typu kanałów do prezentacji własnego dorobku naukowego. Wspótpraca bibliologicznych ośrodków naukowych w świetle sieciowej analizy publikacji była tematem referatu Magdaleny Paul (IINiSB UW). Autorka podjęła próbę odpowiedzi na pytania, w jaki sposób polscy bibliolodzy wybierają czasopisma, w których chcą zamieścić opis i wyniki swoich badań (niestety na podstawie analizy sieciowej nie dowiemy się nic na temat motywacji wyboru danego czasopisma) i czy na podstawie analizy ich publikacji można stworzyć sieć rysujących się w ten sposób kontaktów naukowych i współpracy pomiędzy ośrodkami naukowymi? Lidia Jarska (IINiB UMCS) przedstawiła ostatni tego dnia referat pt. Pracownik naukowy w mediach społecznościowych - od popularyzacji nauki do kreowania wizerunku. Prelegentka mówiła o tym, że pracownicy naukowi posiadają konta zarówno na najpopularniejszych portalach społecznościowych (Facebook, Twitter), jak i zawodowych (GoldenLine, LinkedIn) i mimo że te serwisy społecznościowe nie są serwisami naukowymi sensu stricto (jak Academia.edu, ResearchGate czy Mendeley), służą do nawiązywania i utrzymywania kontaktów naukowych, prowadzenia dyskusji naukowych, wymiany doświadczeń na tematycznych profilach naukowych, profilach osobistych, w grupach dyskusyjnych. Wskazała, że w tym kontekście ważne jest, by tworzony na portalach społecznościowych wizerunek był profesjonalny i spójny, bo nieumiejętne operowanie tego typu narzędziami może skutkować całkowicie odwrotnym zaprezentowaniem się w sieci.

$\mathrm{Na}$ koniec części formalnej pierwszego dnia zaplanowano dyskusję, którą również moderował dr hab. Z. Gębołyś, prof. UKW. Dyskusja dotyczyła pojmowanie i przejawów współczesnego bibliofilstwa (Arkadiusz Wagner z IINiB UMK i G. Piechota), M. Świgoń mówiła o błędzie polegającym na ocenianiu humanistów taką samą miarą, jak przedstawicieli nauk ścisłych, Z. Osiński wspominał o zbyt wielkiej ufności względem danych pozyskiwanych $\mathrm{z}$ analizowanych $\mathrm{w}$ referatach baz danych, Wiesław Babik pytał o przejawy współpracy bibliologów z różnych ośrodków w kontekście danych 
z badań sieciowych, a Ewa Rozkosz skierowała do przedstawicielki serwisu Academica pytanie o skanowanie przez nich książek born digital z wersji papierowych (odpowiedź była twierdząca), na koniec w dyskusję włączyła się Lidia Derfert-Wolf, próbując zestawić funkcjonalności narzędzia Academica i repozytorium dziedzinowego e-LIS, zachęcając do deponowania w tym ostatnich swoich tekstów.

Rozmowy kuluarowe toczyły się podczas zaplanowanego bankietu, zorganizowanego w holu głównym Collegium Humanisticum, podczas którego uczestnikom konferencji czas umilił koncert jazzowy zespołu Szczerbate Zajączki Trio przy gościnnym udziale Magdaleny Cyrklaff, absolwentki studiów magisterskich i doktoranckich w zakresie bibliologii i informatologii na UMK.

Drugiego dnia konferencji obrady w sesji piątej „Konteksty i narzędzia komunikacji sieciowej” moderowane były przez prof. Wiesława Babika (IINiB UJ). Pierwszy referat wygłoszony został przez Katarzynę Materską (Biblioteka UKSW w Warszawie) i nosił tytuł Infonada - przyczynek do ekologii informacji w polskim środowisku naukowym. Autorka zaprezentowała kanały i narzędzia służące zwiększaniu stopnia dzielenia się wynikami prac badawczych. W kontekście dużej liczby dostępnych informacyjnych baz danych autorka poddała analizie problem dostępu do informacji naukowej i jej jakości oraz przyjrzała się temu, w jakim stopniu wymienione w referacie serwisy (Polon, Pol-Index, Infona, Synat, CEON, Wirtualna Biblioteka Nauki, repozytoria i archiwa, biblioteki cyfrowe, portale, bazy cytowań) ułatwiają sprawne docieranie do potrzebnej informacji i w jakim zakresie stają się one częścią codziennego warsztatu informacyjnego w bibliotekach akademickich. W dalszej części obrad głos zabrał Z. Osiński (IINiB UMCS), który w referacie Historia Polski w czasopismach indeksowanych $w$ bazie Scopus zaprezentował wyniki badań przeprowadzonych w wyniku analizy jakościowej i eksploracji bazy Scopus, a dotyczących zainteresowań badawczych z zakresu dziejów Polski wśród badaczy spoza naszego kraju. Następny referat pt. Platforma badawcza dla badań transdyscyplinarnych jako podstawa teoretyczna dla wymiany informacji, wiedzy i doświadczeń został przedstawiony przez Tomasza Komendzińskiego (Instytut Filozofii UMK). Na przykładzie analizy komponentów platformy badawczej dla nauk kognitywnych, zaprezentował on programy badawcze, będące częścią platformy i stanowiące płaszczyznę wymiany informacji, doświadczeń i wiedzy. Referat wygłoszony przez Pawła Marca (KINiB UKW w Bydgoszczy), pt. Optymalizacja serwisów internetowych dla urzadzeń mobilnych na przykładzie techniki projektowania stron responsywnych, skoncentrowany był na analizie rozwiązań technicznych stosowanych przy projektowaniu stron responsywnych, z wykorzystaniem urządzeń mobilnych, ze szczególnym uwzględnieniem serwisów bibliotek. Z kolei Kamil Stępień (IINiB UMCS) w referacie Zastosowanie technologii rzeczywistości rozszerzonej (AR) w wizualizacji informacji, zaprezentował przykłady technologii wykorzystującej rzeczywistość rozszerzoną do prezentowania informacji w czasie rzeczywistym. Na przykładzie projektu open source „Google Cardboard” przybliżone zostały możliwości samodzielnego stworzenia trójwymiarowych okularów, których używanie w połączeniu z dedykowanymi, ogólnodostępnymi aplikacjami i smartfonem pozwala na oglądanie rzeczywistości w 3D. Ostatnim referentem w sesji był Krzysztof Szymański (Elsevier), który w referacie Jak zwiększyć widoczność dorobku uczelni zaprezentował sposoby na wzmocnienie wizerunku zarówno jednostek naukowych, jak i pojedynczych osób poprzez narzędzia służące do popularyzacji i eksponowania wyników badań, które w ocenie prelegenta mogą zwiększyć szanse jednostek na pozyskanie grantów i stanowią przestrzeń służącą do budowania spójnego źródła informacji o prowadzonych badaniach naukowych i ich wynikach.

Ostatnia sesja, zatytułowana „Rola biblioteki w komunikacji naukowej”, była moderowana przez dr hab. Małgorzatę Fedorowicz-Kruszewską (IINiB UMK). W sesji zaplanowane zostały cztery referaty, z których pierwszy zaprezentował Igor Góźdź (Tabulus). W prezentacji Przestrzeń informacyjna w biznesie - Back Office na przykładzie modelu outsourcingowego Back Office przedstawił procesy optymalizujące obieg informacji i dokumentów w świecie biznesu. Z kolei wystąpienia L. Derfert-Wolf (Biblioteka UTP w Bydgoszczy, EBIB), pt. Ksztatcenie umiejętności korzystania z danych badawczych (Data Information Literacy), dotyczyła związków z koncepcją edukacji informacyjnej, zagranicznych projektów modeli kształcenia umiejętności korzystania z danych oraz znaczenia, możliwości i roli 
bibliotekarzy akademickich w rozwijaniu kompetencji z zakresu information literacy wśród użytkowników bibliotek. Wyniki przeprowadzonych badań na temat wykorzystania czytników książek elektronicznych w bibliotekach zaprezentowała Julita Niedźwiecka-Ambroziak (Biblioteka Wyższej Szkoły Bankowej w Toruniu), w referacie pt. Kolekcje akademickie na czytnikach e-booków. Wdra$\dot{z} a n i e$, funkcjonowanie i badanie użyteczności w Bibliotece WSB w Toruniu. Wykorzystując badania empiryczne dotyczące stopnia zadowolenia oraz wykorzystania e-kolekcji w działalności naukowej i edukacyjnej użytkowników biblioteki WSB, przedstawiła wnioski oraz wskazówki ułatwiające przeprowadzenie wdrożenia i wykorzystania nowoczesnych nośników danych w bibliotekach. Ostatni referat - Rola biblioteki akademickiej w komunikacji naukowej przygotowała Paulina Milewska (Biblioteka UŁ). Autorka omówiła przykłady działań prowadzonych przez biblioteki akademickie, a realizujących nowe zadania i usługi dla środowiska akademickiego, z uwzględnieniem zmian, które nastąpiły wraz z początkiem rewolucji technologicznej.

Zaplanowana na zakończenie drugiego dnia konferencji dyskusja plenarna, podczas której uwaga została skupiona na ostatnim z wygłoszonych podczas konferencji referatów, wywołała wymianę spostrzeżeń pomiędzy zgromadzonymi na sali obrad przedstawicielami różnych ośrodków. Głos w dyskusji zabrała m.in. B. Iwańska-Cieślik, której pytanie do referatu P. Milewskiej dotyczyło skali zjawiska deponowania prac bibliotekarzy naukowych w repozytorium biblioteki. Na poruszone przez prelegentkę zagadnienie rynku publikacji naukowych zareagował również przedstawiciel firmy Elsevier - Krzysztof Szymański, który odniósł się do zarzutów stawianych wobec wydawców komercyjnych, zawłaszczających rynek publikacji naukowych. Obrady zakończyła i podsumowała przewodnicząca Rady Naukowej Konferencji, dr hab. Ewa Głowacka, prof. UMK. Analizie pod względem rozproszenia tematycznego poddała referaty wygłoszone podczas wszystkich sześciu sesji stwierdzając, że dominującymi zagadnieniami były parametryzacja nauki, jej finansowanie oraz problemy związane z ekologią informacji i wykorzystywaniem różnego rodzaju narzędzi do pracy naukowej. Prof. E. Głowacka wyraziła podziękowania dla uczestników, sponsorów konferencji, jej patronów medialnych i honorowych. Organizatorzy konferencji zapowiedzieli publikację wygłoszonych referatów i głosów w dyskusji.

Monika Halasz-Cysarz Instytut Informacji Naukowej i Studiów Bibliologicznych Uniwersytet Warszawski

Piotr Rudera Instytut Informacji Naukowej $i$ Bibliologii Uniwersytet Mikołaja Kopernika w Toruniu

Nadestano: 6.07.2015. 